\title{
PLANNING SOIL TILLAGE USING QUALITY FUNCTION DEPLOYMENT (QFD)
}

\author{
Marcos Milan ${ }^{1 *}$; José Wandmark Duarte Barros²; José Luiz Gava ${ }^{3}$ \\ ${ }^{I}$ USP/ESALQ - Depto. de Engenharia Rural, C.P.9 - 13.418-900 - Piracicaba, SP - Brasil. \\ ${ }^{2}$ EAFS - 5700-200 - Satuba, AL - Brasil. \\ ${ }^{3}$ Companhia Susano de Papel e Celulose - Rod. Raposo Tavares, km 169 - 18200-000 - Itapetininga, SP - Brasil. \\ *Corresponding author <macmilan@esalq.usp.br>
}

\begin{abstract}
The Brazilian forest sector represents about 4\% of gross domestic product (GDP) which is correspondent to US\$ 21.0 billion. The natural forest area is approximately 4.8 million hectares and for the near future there will be a need to increase the planted area. To avoid or minimize the impact of mechanized practices on forest soils, the reduced tillage has been developed. The aim of this work is to define the technical priorities of the reduced tillage for eucalyptus seedlings, using quality function deployment (QDF). The design requirements classified as the most important to attend seedling demands were the furrow width and depth, and clod sizes. QFD has the potential to be applied to agro-forestry systems to translate plant demands into technical requirements.

Key words: QFD, quality, mechanization, soil tillage, forestry
\end{abstract}

\section{PLANEJAMENTO DO PREPARO DO SOLO POR MEIO DO DESDOBRAMENTO DA FUNÇÃO QUALIDADE (QFD)}

\begin{abstract}
RESUMO: O setor florestal brasileiro representa aproximadamente $4 \%$ do produto interno bruto, valor estimado em US\$ 21 bilhões. As florestas denominadas artificiais, ocupam ao redor de 4,8 milhões de hectares sendo previsto uma necessidade de ampliação para atender a demanda futura, além do replantio das áreas cohidas. Uma das preocupações com essas áreas é evitar a compactação do solo devido as operações mecanizadas e uma das técnicas é o preparo reduzido. O objetivo deste trabalho é definir as prioridades do preparo do solo de acordo com as necessidades da muda de eucaliptus; para tanto utilizou-se da função desdobramento da qualidade (QFD) para identificá-las. Os requisitos técnicos largura e profundidade do sulco e tamanho dos torrões foram os mais importantes para atender as demandas das mudas. O QFD é uma técnica que tem potencial de aplicação, tanto na área florestal como agrícola, para identificar e traduzir as demandas das culturas em requisitos técnicos.

Palavras-chave: QFD, qualidade, mecanização, preparo do solo, floresta
\end{abstract}

\section{INTRODUCTION}

The Brazilian natural forest sector has great economical importance for the country. The sector represents about $4 \%$ of gross domestic product (GDP) which corresponds to US $\$ 21$ billion or $8 \%$ of the exports. It pays US\$ 3 billion in taxes per year and accounts for 2 million jobs, both direct and indirect. The planted pinus area comprises approximately 1.8 million hectares, and eucalyptus 3.0 million (Garlipp, 2001). Together, they equal the sugarcane planted area, approximately 4.86 million hectares, Brazil being the largest producer (Cunali de Felippe, 2001).

The reduction of the wood stock in Brazil foreseen for the year 2006 demands an enlargement of the natural forest planted area to 630 thousand ha per year (Garlipp, 2001). Currently nowadays Pinus and Eucalyptus spp. correspond to 200 thousand hectares planted per year, which is much less than necessary. Part of this area will be located at places where machinery and truck traffic may cause soil compactation and consequently reduce forest productivity (Seixas, 2000).

To avoid or to reduce the impact of mechanized management practices on forest soils the reduced tillage concept is being adopted. To evaluate the operation quality, an index should be developed. The index "depth" was used by Corrêa et al. (1991) to evaluate the quality of the subsoiling operation, and by Trindad (1993) for harrowing. This operation was also evaluated by Dallmeyer (1994), Boller et al. (1995) and Milan \& Fernandes (2002) using clod sizes. Nevertheless, before developing an index it is necessary to define "WHAT" plants demand from the operation, "HOW" and "WHICH" items are the most important to supply the technical demands, and only then defining the quality index and the available ways to perform it.

The industrial concept of "listening to customer's demands" started in the 1960's in Japan. It was created 
and developed by Akao, between 1960 and 1965, and was called Quality Function Deployment - QFD (Cheng et al, 1995). QFD is defined by Akao (1990) and by the American Society for Quality-ASQ (2001) as a method to develop the quality aiming customers satisfaction, translating his demands into project objectives and reassuring the quality through manufacturing stages. The method supplies the means for people of different assignments to participate in the resolution of some problems, implying that all the company staff should cooperate, interacting to assist the internal or external customer on his demands (Hauser \& Clausing, 1988). The major point of QFD is the chart named "house of quality" where the customer demands on "WHAT" are translated into design characteristics, "HOW" into the basis of market research and past experiences, and "WHY" into scores (Govers, 2001). Considering Eucalyptus spp. seedlings as customers, which have their soil requirements for growth, the purpose of this work is to define the technical priorities of the subsoiling operation, used in the reduced tillage to attend seedlings, introducing QFD concepts.

\section{MATERIAL AND METHODS}

The general method for the development of this work was an adaptation of Akao's (1990) proposal. It consists on identifying demands of Eucalyptus spp. seedlings which is the customer of tillage operations, and to schedule them using the "house of quality." To obtain the seedlings demands and translate then into design characteristics, a series of meetings with a team of experts was performed. The team was composed of seven technicians who work in a natural forest cellulose and paper industry of the state of São Paulo, Brazil. The meetings were coordinated by an external member, called facilitator. The facilitator is responsible for the orientation and the collection of the information for the construction of the "house of quality". An outline is presented in the Figure 1 , and is used as base for methodologic description.

The first stage was to define, organize and classify the items "WHAT" (Figure 1) of the demanded quality by seedlings. The team was requested, through the "brain writing" technique, to answer the question "What are the demands of the Eucalyptus spp. seedlings related to the reduced tillage using a subsoiler implement?" Items i1 to $\underline{i m}$ were defined, organized and classified in the form of a tree diagram of horizontal branches with the technical support of the facilitator. The following step was to know how the products of the competitors matched up to the customer requirements, as compared to the organization product through the definition of the Importance Rating and Competitive Benchmarking "WHY".

The Importance Rating for each item "WHAT", i1 to im, was classified by the team using weights from 1 (low) to 5 (high). The Comparative Benchmarking was made by the comparison of a forest site named NF5 against forest sites NF4A and NF6. For each item "WHAT" regarding the forest sites NF5, NF4A and NF6, scores from 0 to 5 were given according to Akao (1990). The Importance Rating means how each item "WHAT" is priority for the seedling. The Competitive Benchmarking shows how the seedling is satisfied with the characteristics of the forest site NF5 in comparison to competitors NF4A and NF6. At this stage, the Planned Quality is determined, representing the improvement required to reach NF5 for each item, according to the evaluation team.

The next step was to define the design requirements that result from the translation of customer requirements into technical specifications. At this stage the team

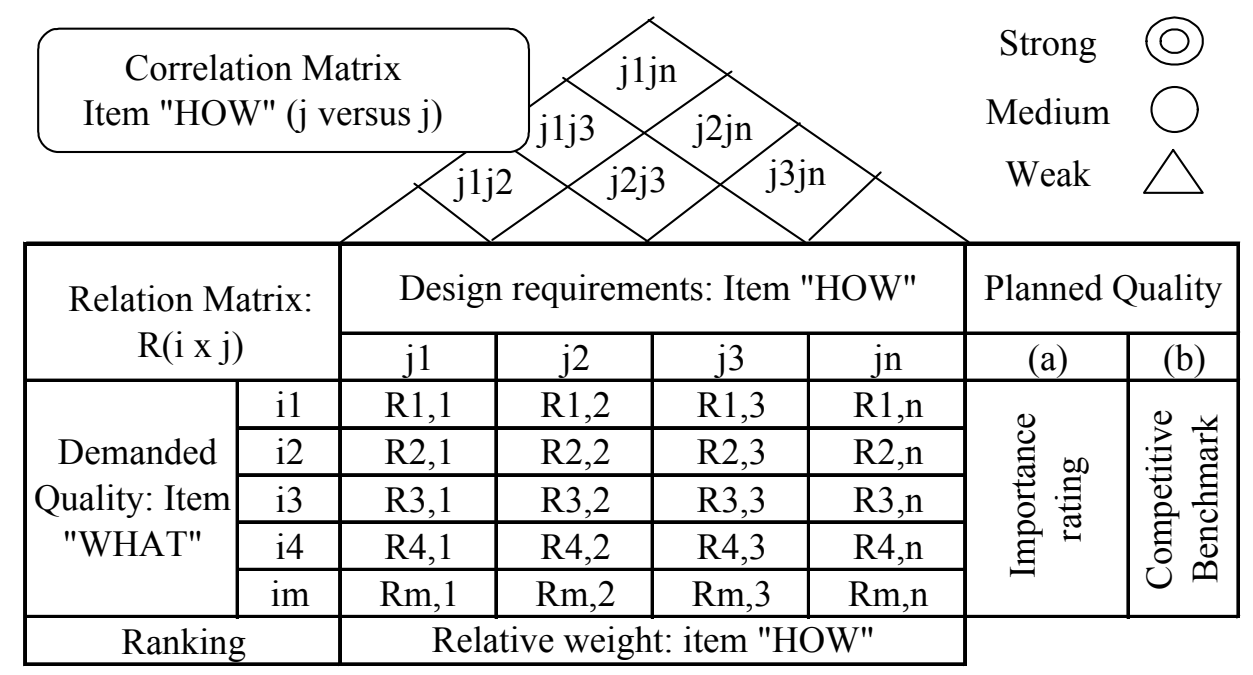

Figure 1 - The "House of Quality" basic structure. 
involved in the process defined the items "HOW" (Figure 1), based on technical knowledge of the subject. After that, the strength of the relations between "WHAT" and "HOW" (relation matrix) was defined by the team, using symbols and weighting factors. Triangles mean weak, and their weighting factor is 1 ; circles mean medium, and their value is 3 ; and double circles mean strong, and their value is 9. The value of each cell Rij (Figure 1 ), is calculated through the weights associated to the symbols, multiplied by the Importance Rating value, using Equation (1):

$$
\mathrm{W}(\text { cell })=\mathrm{a} \times \mathrm{Rij}
$$

where W(cell) is the calculated value for each Rij cell; a- Importance Rating value; and Rij - weighing factor associated to the symbols (1-3-9).

The absolute weights of the items are calculated by adding the values for each column jm [Equation (2)], and it provides the importance of each HOW in achieving the collective "WHAT".

$$
\mathrm{WA}(\text { column })=\sum \mathrm{W}(\mathrm{jm})
$$

where WA(column) is the absolute weight associated to the Design Requirement jm; W(jm) is the value of each ij cell in column jm.

The relative weight of the Design Requirements was obtained from the Equation (3):

$\mathrm{WR}(\%)=\left[\mathrm{W}(\right.$ column jm $) \div \sum \mathrm{W}($ column $\left.)\right] \times 100$ (3)

where WR (\%) is the relative weight (\%) of each Design Requirement jm; W(column jm) the absolute weight of the Design Requirement jm; and $\sum \mathrm{W}$ (column) the total absolute weights of the columns .

The Correlation Matrix (HOW versus HOW or j versus j) of Figure 1 shows the support and conflict between Design Requirements. Different degrees of interaction, analyzed by the team, were represented by the symbols triangle, circle, and circle with a dot.

\section{RESULTS AND DISCUSSION}

The House of the Quality (Figure 2) will be used for the discussions. The results from "WHAT" items show that the demanded quality by Eucalyptus seedlings related to the reduced tillage have the objective to maintain the natural forest productivity through physical, chemical and biological soil phenomena. "Hold water and nutrient supply" appears in two places. First in the chemical requirement, refering to the reactions of the water with soil aggregates; second in the physical requirement, refering to the water flow through soil macro porosity.
The Importance Rating showed a strong relation in the items related to the physical requirements. "Without physical limitation", "Physical support for plants" and "No limiting slash for mechanization" were the most important items with scores of 5.0, 4.7 and 4.3 points, respectively. The Competitive Benchmarking had the best performance of the forest site NF5 for the chemical requirements when compared to sites NF4A and NF6. For the biological requirements the NF5 had the highest score for the item "Promote biological activity". For the physical requirements the forest site NF5 had the lowest score for "Satisfactory drainage", "Without physics limitation" and "No limiting slash for mechanization" as compared to sites NF4A and NF6. The lowest scores given for the items "Satisfactory drainage" and "Without physics limitations" indicates that NF5 has the worst natural soil conditions as compared to NF4A and NF6. It is important to emphasize, at this point, that the evaluations were made based on the perception of this particular team of experts.

Planned Quality established goals, defined by the team, to be reached by NF5 for each item. For the chemical requirements the plan is to maintain the current values. For the biological requirement the item "Free from weeds and diseases" is intended to reach NF6 and for the physical requirements all the items needed to be improved except for the "Hold water and nutrient supply"

The design requirement tractor/implement/operator is obtained at a second level by operational results and registered occurrences. The choice of "depth" and "clod size" as quality indexes for the reduced tillage is in accordance with Corrêa et al. (1991), Trindad (1993), Dallmeyer (1994), Boller et al. (1995), and Milan \& Fernandes (2002).

The relation matrix WHAT versus HOW (Figure 2), presents the interaction of each Design Requirement versus the Demanded Quality. "Width", "depth" and "clod size" interact with all Demanded Quality items but the exception was "clod size" versus "free from weeds and diseases". These three requirements were classified as the most important for obtaining the seedling demands. The relation between "depth" and "without physical limitation" was considered strong (double circle) and the explanation is that the "depth" variability of the subsoiling operation may modify soil structure in the furrow.

The absolute weight for "width", "depth" and "clod size" were 269.6; 261.8 and 234.8 , representing $26.4 \% ; 25.7 \%$ and $23.0 \%$ of the total, respectively. These three requirements have $75.1 \%$ of the total assigned weights evidencing the priority of the three items. The analysis of the values of the design requirements for the three forest sites reveals that NF5 has currently the smallest width and depth of furrows. The team chose the value of $0.60 \mathrm{~m}$ for furrow width as the value to be reached by NF5 in the future, the Projected Quality. 


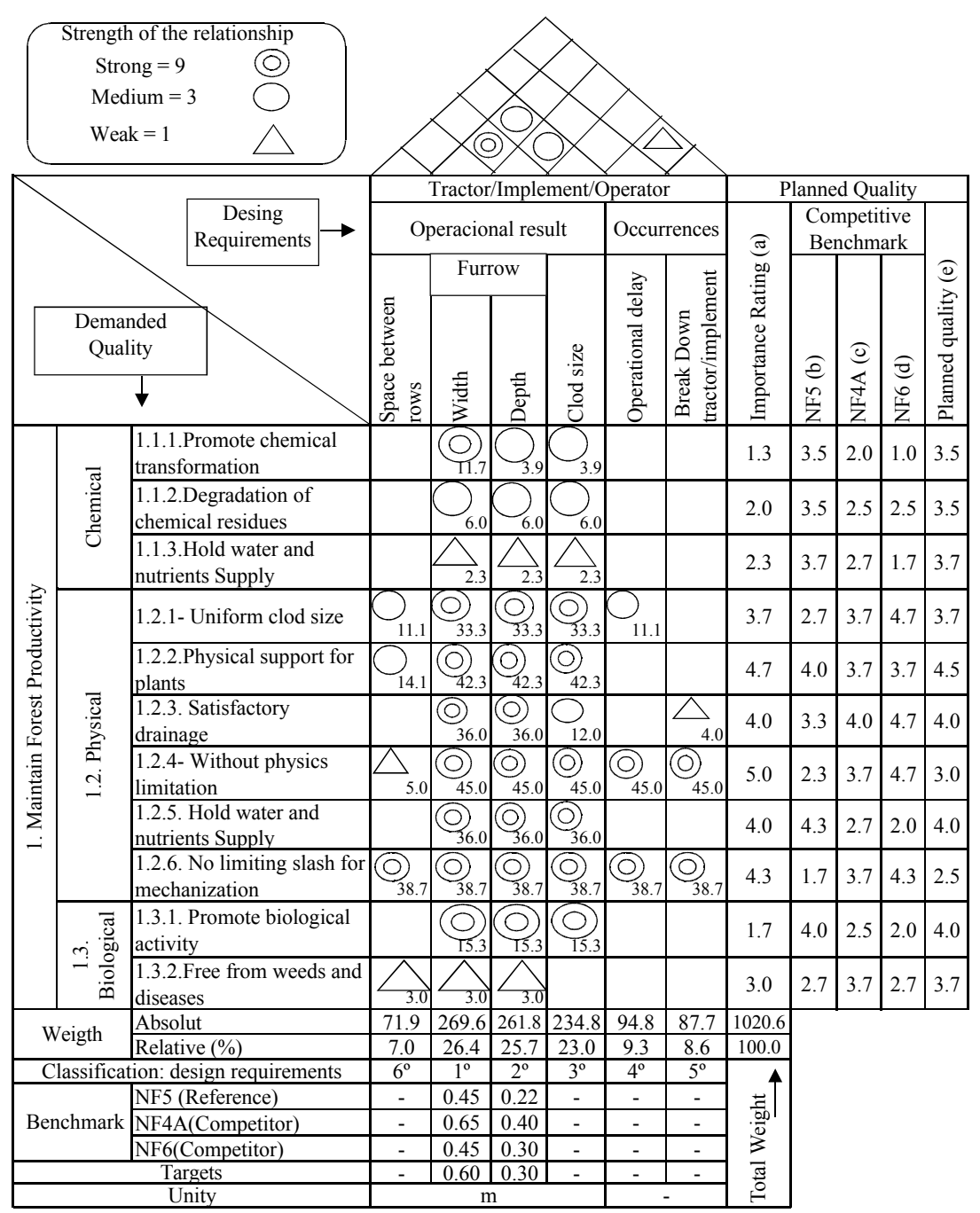

Figure 2 - "House of Quality" of the reduced tillage, using a subsoiler, to attend Eucaliyptus spp. seedlings.

The technical requirement correlation matrix shows a strong positive correlation between "width" and "depth" items. Any change in one of these itens causes a positive alteration in the other. In practice it means that increasing depth of the furrow increases the width.

\section{CONCLUSIONS}

The most important requirements for the customer, Eucalyptus spp. seedling, were the items "Without physics limitation", "Physical support for the plants" and "Without vegetation that limits mechanization" scoring 5.0, 4.7 and 4.3 points respectively.

"Width", "Depth" and "Clod size" were the most important items of the design requirements, reaching $75.1 \%$ of the relative weight. The Eucalyptus spp. seed- ling priorities are attended by the control of the furrow depth. Quality function deployment, (QFD) has potential to be applied to forestry and agricultural systems to translate plant demands into technical requirements.

\section{ACKNOWLEDGEMENTS}

To Companhia Suzano de Papel e Celulose and their collaborators Danilo da Silveira Chausson, José Luiz Gava, Martinho de Araújo, Luiz Ronick, Joel Madela, Luiz Carlos Cabral, Wagner H. Itria Jr. for the support and participation. To CAPES for the financial support, and Prof. C.A.S. Andriani for technical support.

\section{REFERENCES}

AKAO, Y. Quality function deployment: integrating customer requirements into product design. Portland: Maple-Vail, 1990. 369p. 
AMERICAN SOCIETY QUALITY. Asq glossary of terms. 2001. www.asq.org/info/glossary/definition.htm\#o. (02 nov. 2001).

BOLLER, W.; GAMERO, C.A.; MACIEL, A.J.S. Qualidade do preparo de solo com grade em função das regulagens e da utilização de discos esféricos e cônicos. Engenharia Rural, v.6, p.1-9, 1995.

CHENG, L.C.; SCAPIN, C.A.; OLIVEIRA, C.A.; KRAFETUSKI, E.; DRUMOND, F.B.; BOAN, F.S.; PRATES, L.B.; VILELA, R.M. QFD: planejamento da qualidade. Belo Horizonte: UFMG; Escola de Engenharia; Fundação Christiano Ottoni, 1995. 262p.

CORRÊA, I.M.; YANAI, K.; PECHE FILHO, A.; MAZIERO, J.V.G.; MENEZES, J.F.; PECHE, A.T.M. Subsolador vibratório: II. Mobilização do solo com e sem acionamento do mecanismo de vibração. Engenharia Rural, v.2, p.15-18, 1991.

CUNALI DE FELIPE, E. Tendências mundiais para a colheita mecanizada da cana-de-açúcar. In: SEMINÁRIO DE MECANIZAÇÃO E PRODUÇÃO DE CANA-DE-AÇÚCAR 2001, 3., Ribeirão Preto, 2001. Ribeirão Preto: Instituto de Desenvolvimento Agroindustrial, 2001. p. 56-60.

DALLMEYER, A.U. Avaliação energética e desempenho operacional de equipamentos de preparo de solo. Botucatu: UNESP/FCA, 1994. 156p. (Tese - Doutorado)
GARLIPP, R.C. Projetos florestais de seqüestro de carbono. In: SEMANA FIESP/CIESP DE MEIO AMBIENTE, 3., São Paulo, 2001. www.sbs.org.br/mudanças_climáticas_internet.ppt. (02 nov. 2001)

GOVERS, C.P.M. What and how about quality function deployment (QFD). International Journal of Production Economics, v.46-47, p.575-585, 1996.

HAUSER, J.R.; CLAUSING, D. The house of quality. Harvard Business Review, p.63-73, May/June, 1988.

MILAN, M; FERNANDES, R.A.T. Qualidade das operações de preparo do solo por controle estatístico do processo. Scientia Agricola, v.59, p.261266, 2002.

MAZUR, G. Brief introduction to qfd: history. 2001. www.mazur.net/ htm\#HISTORY. (02 nov. 2001).

SEIXAS, F. Compactação do solo devido á colheita de madeira. Piaracicaba: USP/ESALQ, 2000. 75p. (Tese - Livre-Docência)

TRINDAD, C. Desenvolvimento de um sistema de controle de qualidade para a atividade florestal. Viçosa: UFV, 1993. 164p. (Dissertação Mestrado)

Received February 05, 2002 